\title{
Flowering phenology of Mouriri guianensis (Melastomataceae) and its interaction with the crepuscular bee Megalopta amoena (Halictidae) in the restinga of Lençóis Maranhenses National Park, Brazil
}

\author{
Fabiana dos Santos OLIVEIRA¹, Monique Hellen Martins RIBEIROํㅜ, Cecilia Veronica NUNEZ², Patricia \\ Maia Correia de ALBUQUERQUE ${ }^{1 *}$. \\ 1 Universidade Federal do Maranhão, Departamento de Biologia, Avenida dos Portugueses, 1966, CEP 65080-805, São Luís, Brasil. \\ 2 Instituto Nacional de Pesquisas da Amazônia, Coordenação de Tecnologia e Inovação, Avenida André Araújo, 2936, Petrópolis, CEP: 69067-375, Manaus, Brasil. \\ * Corresponding author: patemaia@gmail.com
}

\begin{abstract}
Mouriri guianensis is a Brazilian endemic plant species distributed throughout the Amazon forest, Caatinga, Mata Atlântica and Cerrado domains, extending northward into Venezuela. The aim of this study was to describe the flowering phenology, floral biology and visitors associated with M. guianensis, highlighting the crepuscular bee species Megalopta amoena. Mouriri guianensis flowers from September to March. The flowering, the details of floral biology and the activities of floral visitors were observed for ten individual plants in December 2013, January-March 2014, September-December 2014 and JanuaryMarch 2015. The flowering peaks occurred in December 2013 and in November-December 2014. Bees were collected in January and February 2015. A total of 86 individuals belonging to six bee species were recorded visiting the flowers, with Xylocopa cearensis making more than one-half of the visits (60\%), followed by Melipona subnitida and Megalopta amoena with $21.17 \%$ and $9.41 \%$ of the visits, respectively. The visitors showed activity peaks between 5:00 and 6:00 AM (66.27\%). Buzz pollination was their predominant behavior. Megalopta amoena used its jaws to open the pore and the anther gland. Melipona subnitida used parts of the glands to seal the entrance to the colony. The visitors, except for Augochlopsis sp. and Trigona sp., are pollinators of $M$. guianensis. Plants having an extended anthesis can attract visitors both day and night. In this study, we present an example of a crepuscular pollination system. We suggest that blooming at twilight is a strategy used by the plant to escape unsuitable visitors.
\end{abstract}

KEYWORDS: Pollination, insect-plant interaction, floral oil, crepuscular foraging.

\section{Fenologia da floração de Mouriri guianensis (Melastomataceae) e sua interação com a abelha crepuscular Megalopta amoena (Halictidae) na restinga do Parque Nacional dos Lençóis Maranhenses, Brasil}

\begin{abstract}
RESUMO
Mouriri guianensis é uma espécie vegetal endêmica do Brasil, distribuindo-se pelos domínios da Floresta Amazônica, Caatinga, Mata Atlântica e Cerrado, chegando ao norte até a Venezuela. O objetivo do estudo foi descrever a fenologia de floração, a biologia floral e os visitantes florais de M. guianensis, com destaque para as abelhas crepusculares Megalopta amoena. Mouriri guianensis floresce de setembro a março e a floração de dez indivíduos foi acompanhada em dezembro/2013, janeiro-março/2014, setembro-dezembro/2014, janeiro-março/2015, sendo observados aspectos da biologia floral e visitantes. Os picos de floração ocorreram em dezembro/2013 e novembro-dezembro/2014. As abelhas foram coletadas em janeiro e fevereiro de 2015. Um total de 86 indivíduos de seis espécies de abelhas foi registrado visitando as flores com Xylocopa cearensis realizando a maioria das visitas (60\%), seguida por Melipona subnitida e Megalopta amoena com 21,17\% e 9,41\%, respectivamente. Os visitantes mostraram picos de atividade entre 5:00 - 6:00 h (66,27\%). O comportamento predominante foi o de vibração. Megalopta amoena utilizou suas mandíbulas para romper os poros da antera e glândula. Melipona subnitida utilizou partes das glândulas para a vedação da entrada da colônia. Os visitantes, a exceção de Augochlopsis sp. e Trigona sp., são polinizadores de M. guianensis. Plantas com longos períodos de antese podem atrair visitantes diurnos e noturnos. Aqui demonstramos um exemplo de sistema de polinizaçáo crepuscular, sugerindo que o fato florir durante o crepúsculo é uma estratégia da planta para escapar de visitantes inoportunos.
\end{abstract}

PALAVRAS-CHAVE: Polinização, interação inseto-planta, óleo floral, forrageamento crepuscular. 


\section{INTRODUCTION}

Plant-pollinator interaction involves reciprocal adjustments between interacting participants, ultimately leading to interspecific mutualisms or "guild coevolution" (Thompson 1989). The interactions can be studied from combined phytocentric and zoocentric perspectives to identify and understand the pollination syndromes, plant reproductive success, floral visitors, associated behaviors and pollination efficiency (Martins 2013; Freitas et al. 2014).

Floral resources generally mediate the relationship between flowers and visitors. For example, pollen is an essential resource for feeding bees and is also essential in plant reproduction; these two functions are mutually exclusive (Westerkamp 1997; Agostini et al. 2014). The plants must allocate pollen grains to reproduction. They also need bees for pollination, a conflict termed the "pollen dilemma" (Westerkamp 1997).

Accordingly, plants need to make functional adjustments to maintain their visitors. A few examples, among many possible adjustments, are the production of large amounts of pollen grains in the case of "pollen of flowers" (Cruden 2000) and the spatial separation of stamens (heteranthery) present in Senna, Cassia, Chamaecrista and Tibouchina flowers that can guarantee efficient resource allocation and ensure reproduction (Vogel 1974; Buchmann 1983; Vallejo-Marin et al. 2009). Additionally, poricidal anthers, which can provide adaptive advantages to the plant by minimizing pollen harvesting by less efficient visitors (Buchmann 1983), and nocturnal anthesis, in certain species such as Mouriri, could be strategies that facilitate the avoidance of unsuitable visitors (Wcislo et al. 2004).

Mouriri is a Neotropical genus that shows the 'buzz pollination' syndrome, with an absence of nectar in its flowers. However, in addition to providing pollen to its visitors, small epithelial elaiophores are located on its anthers. These structures produce a nonvolatile oil whose specific ecological function of which for the bees remains unknown (Buchmann and Buchmann 1981; Agostini et al. 2014). Mouriri flowers are associated with visitors that are diurnal foragers, including bees belonging to the genera Xylocopa, Trigona, Melipona (Buchmann and Buchmann 1981) and Centris (Oliveira 2010), which are among their main pollinators.

Most bee species are active during the day. However some of them, such as Megalopta (Halictidae, Algochlorini), are adapted to a restricted niche, foraging at twilight, when most bee species are not active (Wcislo et al. 2004; Warrant et al. 2006; Wcislo and Tierney 2009). The aim of this study was to describe the flowering phenology, floral biology and the visitors of Mouriri guianensis, highlighting the crepuscular bees Megalopta amoena.

\section{MATERIALS AND METHODS}

The present study was conducted in an area of restinga within the Lençóis Maranhenses National Park (LMNP), at the settlement Ponta do Mangue (2058'12" S; 42079'56" W), Barreirinhas, Maranhão, Brazil. LMNP has an area of $155.000 \mathrm{ha}$, with $453.28 \mathrm{~km}^{2}$ covered by vegetation, $405.16 \mathrm{~km}^{2}$ of which are predominantly restinga. Mangroves and river bank communities (riparian forests) are also still present in the park (Brasil 2002). The climate of the region is megathermic tropical (Aw' Type, according to the Köppen classification). The mean annual temperature is between 26 and $27{ }^{\circ} \mathrm{C}$. The annual rainfall ranges between 1600 and $1800 \mathrm{~mm}$, with two well-defined seasons: rainy from January to July and dry from August to December (Brasil 2002).

The phenology of ten Mouriri guianensis Aubl. (Melastomataceae) individuals was followed on a fortnightly basis during the study periods December 2013 to March 2014 and September 2014 to March 2015. For the purposes of this study, we have defined the flowering period from the time of the initial formation of the bud until the time that the flowers reach senescence. The periods during which a relatively large number of flowers were in anthesis were considered as the flowering peaks (Newstrom et al. 1994). The collected botanical material was deposited at the Herbarium of the Federal University of Maranhão - MAR.

The flowering pattern of the species was ranked by using the Fournier scale (Fournier 1974), which estimates the intensity of each phenophase in a semi-quantitative manner based on gaps and five categories (0-4). Zero quantity indicates phenophase absence; 1- phenophase presence with a magnitude ranging from 1 to $25 \%$; 2 - from $26 \%$ to $50 \%$; 3 - from $51 \%$ to $75 \%$ and 4 - from $76 \%$ to $100 \%$. Every month, the sum of the phenologic intensity values for all individuals was calculated and divided by the maximum possible value (number of individuals $\mathrm{x} 4$ ). The value obtained was expressed as a percentage (Bencke and Morellato 2002): Fournier (\%) = $\sum$ phenophase $\mathrm{x} 100$ / N x 4. Spearman's correlation (with a 95\% confidence interval) was used to analyze the relationship between meteorological factors (temperature, relative humidity and rainfall) and flowering.

Monthly meteorological data (temperature, relative humidity and rainfall) were provided by the Meteorologic Laboratory/Climatological and Environmental Center of the Maranhão State University (Laboratório de Meteorologia/Núcleo Geoambiental da Universidade Estadual do Maranhão (LABMET/NUGEO). 
Data on anthesis onset, sequence and duration, the number of buds and open flowers per day, the type of reward offered to the visitors, floral longevity and odor emission were obtained in the peak flowering months.

Direct observations of the bees were performed by verifying the visitor type, the harvested reward, the pollen deposition site and the hourly timing and duration of visits. The counts of the number of visits were made based on the number of times the bee alighted on the flowers to harvest the reward. At each hour associated with a collection event, the behavior of the visitor was followed for 15 minutes by taking notes, filming and photographing (Nikon D90, Nikon Corporation, Tokyo, Japan).

The temperature and daily relative humidity were obtained with a digital thermohygrometer (model 7666.02.0.00, Incoterm, Porto Alegre-RS, Brazil). Measurements were made at one-hour intervals.

Floral visitors were collected in January and February 2015 with the use of an entomological net, at first from 6:00 AM to 18:00 PM and then from 18:00 PM to 6:00 AM, for five successive and three full-moon days in January 2015 to cover the entire whole nocturnal visitation period. Later, the observations were made from 04:00 AM to 18:00 PM during 10 non-consecutive days in February 2015. The collected bees were deposited in the bee collection of the Federal University of Maranhão - LEACOL.

To identify the plant species in addition to $M$. guianensis that were visited by Megalopta amoena Spinola throughout the sampling period, the pollen loads from five individuals were acetolyzed using Erdtman's method (Erdtman 1960).

\section{RESULTS}

Flowering in $M$. guianensis occurs from September to March (Figure 1). December 2013 and November/ December 2014 showed relatively large numbers of open flowers. The number of buds was higher from September to January (Figure 1). Flowering showed a significant correlation with relative humidity $\left(r_{s}=-0.7545, p=0.0015\right.$ for buds; $r_{s}=-0.7149, p=0.0018$ for flowers). However, temperature $\left(\mathrm{r}_{\mathrm{s}}=0.2036\right.$ and $p=0.4495$ for buds; $\mathrm{r}_{\mathrm{s}}=$ 0.1653 and $p=0.5406$ for flowers) and rainfall $\left(\mathrm{r}_{\mathrm{s}}=-0.1726\right.$ and $p=0.5226$ for buds; $\mathrm{r}_{\mathrm{s}}=-0.0136$ and $p=0.9601$ for flowers) were not significantly correlated with the studied phenophases.

The M. guianensis plants examined in this study are shrubs nearly $1.5 \mathrm{~m}$ tall possessing white, pentamerous flowers and stamens with yellow, dithecal, poricidal anthers, with elaiophores on their upper part. The stamens are positioned so that the apical pores of the anthers maintain a position in which they are turned downward toward the stigma (Figure 2). The flowers show, on average, seven buds/inflorescence $(7.6 \pm 4.5)$ and from two to three open flowers per day. The flowers offer pollen and oil as rewards. The odor originates from the anthers, calyx and corolla and is strong during the night and until the early morning. Blooming begins at approximately 18:00 PM with the gradual separation of the petals and is over by approximately 4:00 AM. Floral longevity is short, and by approximately 9:00 AM, the flower already holds anthers bearing no pollen and darkened elaiophores.

We recorded a total of 86 individuals from two subfamilies and six species of Apidae in approximately 250 hours of observation. Xylocopa cearensis Ducke conducted more than half of the visits (60\%), followed by Melipona subnitida Ducke and Megalopta amoena with $21.17 \%$ and $9.41 \%$ of the visits, respectively (Table 1 ).

Megalopta amoena bees were the first visitors, starting their foraging activity approximately 5:00 AM and ending it at 5:35 AM, visiting few flowers and remaining in them for nearly 23 seconds $(22.9 \pm 1.19)$. No visits of this species were observed at any other time.

The sampling of the pollen load found in the scopes of $M$. amoena showed $88.5 \%$ from $M$. guianensis and $17.6 \%$ belonging to other plant species [6\% Machaerium type (Fabaceae), 4\% Protium heptaphyllum (Aubl.) March (Burseraceae), 2\% Mimosa misera Benth. (Mimosaceae), 1.5\% Astrocaryum sp. (Arecaceae), 1\% Anacardium microcarpum Ducke (Anacardiaceae), 1\% Myrcia obtusa Shauer (Myrtaceae), 1\% Xyris paraensis Poepp. (Xyridaceae), 0.6\% Hyptis type (Labiateae), 0.5\% Tabebuia type (Bignoniaceae)].

Melipona subnitida bees began their activities at 5:30 AM and ended at approximately 8:00 AM, while Xylocopa (X. cearensis and Xylocopa grisescens Lepetelier) bee species initiated their harvesting activities at approximately 6:00 AM. As a whole, the visitors concentrated their activity peaks between 5:00 AM and 6:00 AM (66.27\%) (Figure 3). Except for M. amoena, these other bee species remained on the flowers for nearly three to four seconds. Spearman's correlation analyses did not demonstrate significant associations between abiotic factors and bee activities $\left(\mathrm{r}_{s}\right.$ $=-0.38$ and $p=0.1929$ for temperature; $r_{s}=0.46$ and $p=$ 0.1083 for relative humidity).

Buzzing was the predominant harvesting behavior for all studied bees. The collected bees showed no effective floral oil harvesting, and the common specialized bees that harvest floral oil (Centris, Epicharis, Tetrapedia or Tapinotaspidini) were not observed. Nevertheless, $M$. amoena, in addition to the "buzz pollination" behavior (Figure $4 \mathrm{~A}-\mathrm{D}$ ), alighted on the flower, clinging to just one stamen, utilizing its strong jaws to open the anther 

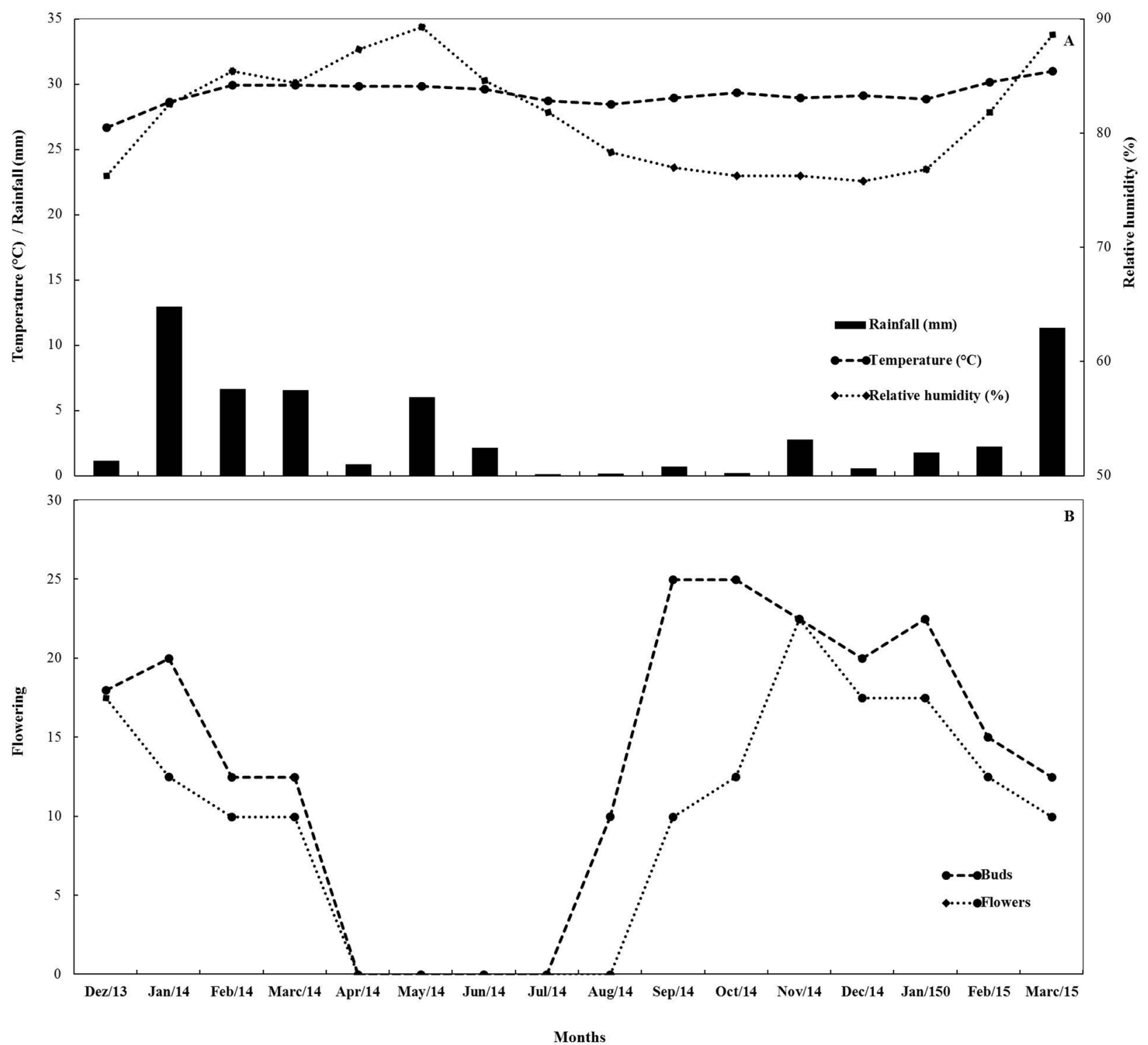

Figura 1. Relationship between flowering phenology (buds and flowers) of Mouriri guianensis Aubl. and abiotic factors (temperature, relative humidity and rainfall), Lençóis Maranhenses National Park, Maranhão, Brazil. A) Rainfall, temperature and relative humidity. B) Flowering.

Table 1. Visiting bees of Mouriri guianensis Aubl. on restinga, Lençóis Maranhenses National Park, Maranhão, Brazil.

\begin{tabular}{lcc}
\hline Family/Tribe/Species & Individuals & (\%) \\
\hline APIDAE & & \\
\hline Meliponini & 18 & 21.17 \\
Melipona (Melipona) subnitida & 1 & 1.17 \\
Trigona sp.* & & 60 \\
\hline Xylocopini & 51 & 7 \\
Xylocopa (Neoxylocopa) cearensis & 6 & \\
Xylocopa (Neoxylocopa) grisescens & & 9.41 \\
\hline HALICTIDAE & & 2.3 \\
\hline Mugochlorini & 8 & 2 \\
\hline Augochloropsis sp. & 2 & \\
\hline
\end{tabular}

${ }^{*}$ not collected species 


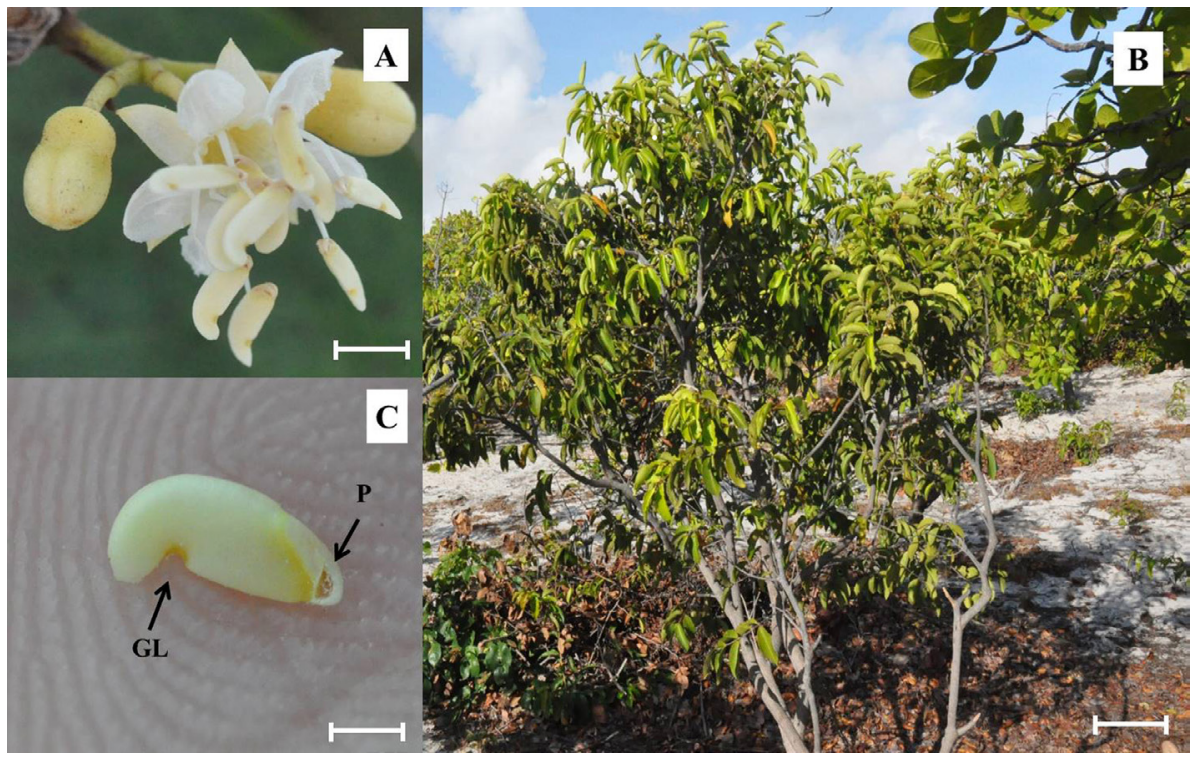

Figure 2. (A) Mouriri guianensis Aubl. flower. (B) General aspect; (C) Anthers indicating apical pore (P) and oil gland (GL), Lençóis Maranhenses National Park, Maranhão, Brazil. Scale bars $=3 \mathrm{~mm}(\mathrm{~A}), 20 \mathrm{~cm}(B)$ and $10 \mathrm{~mm}(C)$. This figure is in color in the electronic version.
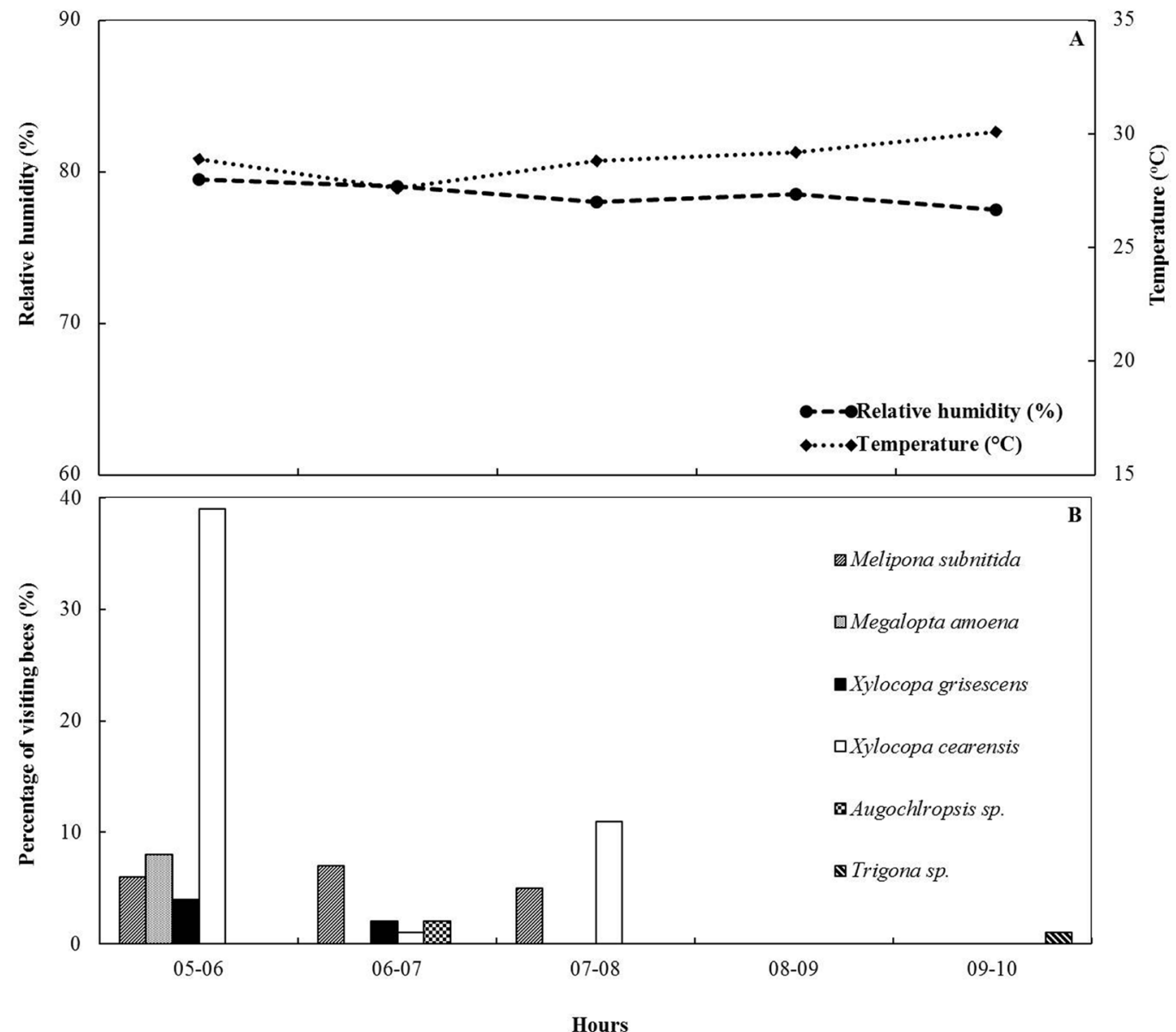

Figure 3. Relationship between Mouriri guianensis Aubl. and bees visiting hours with daily temperature $\left({ }^{\circ} \mathrm{C}\right)$ and relative humidity (\%), Lençóis Maranhenses National Park, Maranhão, Brazil. A) Relative humidity and temperature. B) Percentage of visiting bees. 


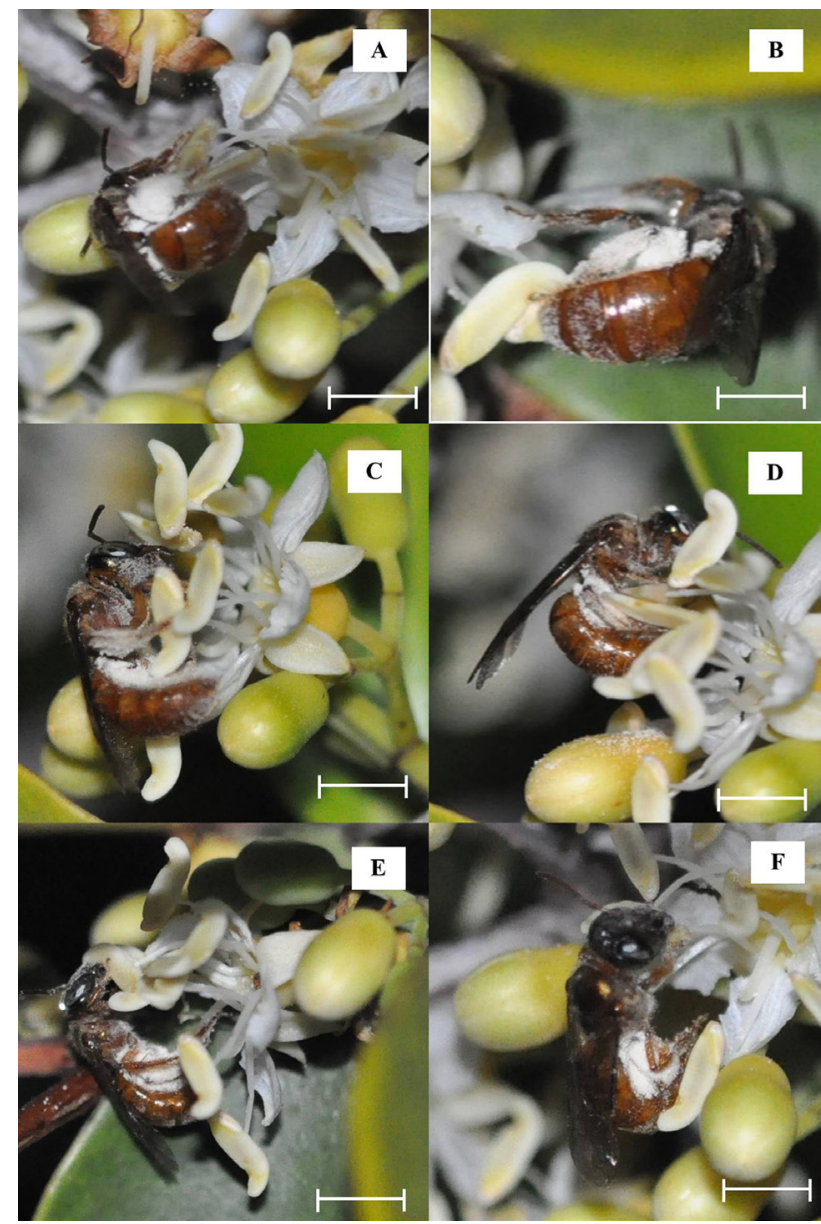

Figure 4. Harvesting behavior exhibited by Megalopta amoena Spinola on Mouriri guianensis Aubl. flowers, Lençóis Maranhenses National Park, Maranhão, Brasil. (A, B, C, D) Pollen harvesting through buzz pollination. (E, F) Bees breaking up the region of the apical pores and glands of the anthers. Scale bars $=6 \mathrm{~mm}(\mathrm{~A}, \mathrm{C}, \mathrm{D}, \mathrm{E}, \mathrm{F})$ and $4 \mathrm{~mm}(\mathrm{~B})$. This figure is in color in the electronic version.

pores and, at times, breaking up the oil gland (Figure 4 E-F), suggesting that this species could show facultative pollen theft.

Melipona subnitida bees harvested pollen from $M$. guianensis and utilized their gland regions to sealing the colony entrances (the colonies were located in nearby manmade boxes) (Figure $5 \mathrm{~A}-\mathrm{B}$ ). We found that the entrance to the boxes was sealed during the night and reopened only by morning (Figure $5 \mathrm{C}-\mathrm{D}$ ). One individual of the genus Trigona was observed harvesting pollen straight from the anthers without contacting the stigmas and scraping the glands with its middle legs. However, this species was not collected. Augochloropsis sp. was only observed flying over the flowers.

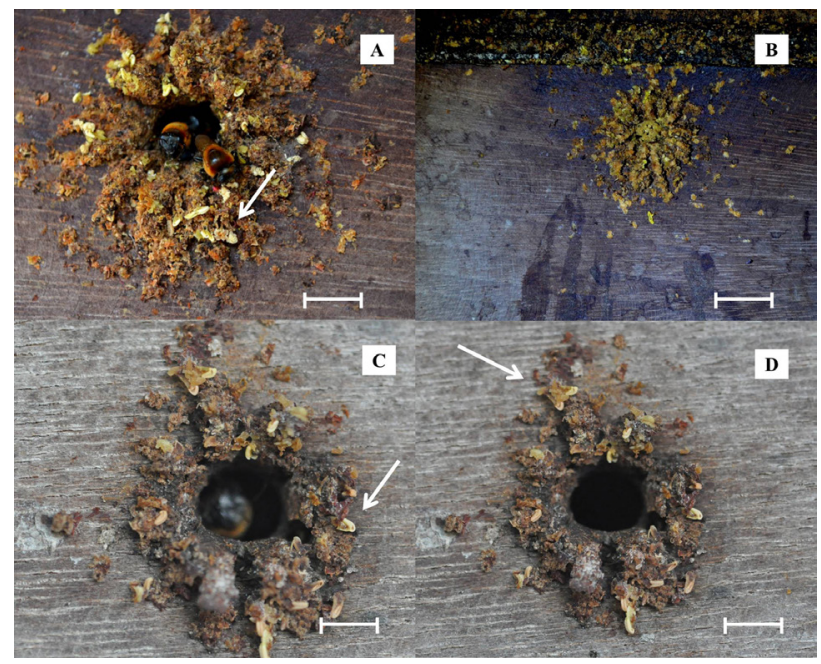

Figure 5. Entrance structure of one man-made box of Melipona subnitida Ducke. (A) Entrance of the box. (B) Box entrance sealing. (C, D) Box entrance open. Arrows showing $M$. guianensis anthers. Scale bars $=10 \mathrm{~mm}(\mathrm{~A}), 20$ $\mathrm{mm}(\mathrm{B}), 15 \mathrm{~mm}(\mathrm{C}, \mathrm{D})$. This figure is in color in the electronic version.

\section{DISCUSSION}

Abiotic factors such as temperature, humidity and rainfall influence the induction and control of flowering and, consequently, activity and interaction with pollinators (Knoll and Santos 2012). In this study, it was noted that with the exception of relative humidity, meteorological factors were not significant in relation to flowering. This could be due to the absence of large fluctuations in monthly temperature averages and precipitation during the studied period. In low-seasonality environments (uniform climates), climatic factors influence the flowering of species in a less obvious way (Locatelli and Machado 2004).

Spearman's correlation analysis involving relative humidity showed that as this climatic variable decreases, flowering increases. In periods of low humidity, the plants increase their evapotranspiration rates considerably, consequently increasing soil water and nutrient input and thereby ensuring that energy reserves are adequate (Odum 1971; Locatelli and Machado 2004). Given the characteristics of the studied area, this may be a physiological strategy used by M. guianensis to ensure adequate energy reserves. Thus, in addition to climatic factors, physiological factors can influence flowering (Locatelli and Machado 2004).

Although M. guianensis flowers attracted bees with diurnal foraging habits such as Xylocopa and Melipona as their more common visitors, nocturnal anthesis and the emission of strong odors during the night represent major attractants for bee species such as $M$. amoena that pollinate flowers based on a pattern of nocturnal or crepuscular melittophily. 
Two crepuscular bee species (Megalopta sodalis Vachal and Ptiloglossa aff. dubia Moure) were found visiting the flowers of Cambessedesia wurdackii Martins, Melastomataceae. Although this plant was sought by diurnal visitors, crepuscular bees were found to be its potential pollinators (Franco and Gimenes 2011).

Plants with an extended anthesis, more than 12 hours, attract diurnal and nocturnal visitors, both of which are effective pollinators of the visited plants (Martins 2013; Aguilar-Rodriguez et al. 2015). A similar result was found in this study, suggesting that bees that visit $M$. guianensis can play a complementary role in pollination (Martins 2013; Aguilar-Rodriguez et al. 2015).

Megalopta amoena starts to forage on flowers before other bees. Accordingly, considering that $M$. amoena has large and robust bees, such as $X$. cearensis and $X$. grisencens, as its main competitors in the study area, its pattern of foraging during the period where the other pollinators are not active increases the reward harvested, reducing the chances for competition and predation (Wcislo et al. 2004).

In contrast, an interesting idea about the resource partitioning and resource sharing is "sensory exclusion", where interactions occur in sensory windows to which less efficient members may not have access (Lunau et al. 2011; Brito et al. 2014). Red flowers pollinated by hummingbirds, for example, represent a color niche that only hummingbirds can identify, as these flowers are inconspicuous to bees (Lunau et al. 2011). This study appears to furnish an example of an interaction mediated by this principle, suggesting that the blooming of the plant at twilight is a strategy to escape from undesirable visitors.

Several studies have previously confirmed that Megalopta are active on plants with poricidal anthers (Wicslo et al. 2004; Franco and Gimenes 2011). Species with diurnal and/or nocturnal anthesis belonging to Anacardiaceae, Bombacaceae, Guttiferae and Melastomataceae were identified as plants that served as a pollen source for Megalopta bees (Wcislo et al. 2004; Smith et al. 2012). Analysis of the pollen loads carried by $M$. amoena suggests that, although $M$. guianensis had been responsible for $88.5 \%$ of the pollen, they also visited many other plant species to harvest this pollen reward, confirming the diffuse nature of most established relationships between plants and pollinators (Martins 2013).

The higher visitation rate of $X$. cearensis to the flowers in the study area may be explained by the observation that Mouriri was the possible source of pollen for this species. Xylocopa bees utilize pollen as food (Viana et al. 2002) and M. guianensis is a plant with abundant pollen. In addition, Xylocopa are efficient pollination agents, mainly for plants such as Mouriri with poricidal anthers (Buchmann 1983). Poricidal anthers could be a strategy for avoiding the harvest of pollen grains by less efficient visitors (Junker and Blüthgen 2010; De Luca and Vallejo-Marin 2013), reducing the numbers of visiting bees, as found in Tibouchina, Comolia and Mouriri (Buchmann and Buchmann 1981; Buchmann 1983; Oliveira-Rebouças and Gimenes 2004). Furthermore, the large quantity of pollen produced and the heteranthery presented by Mouriri flowers may, in part, contribute to mitigate the problem of the "pollen dilemma," guaranteeing their reproductive and feeding success (Vallejo-Marin et al. 2009).

The high visitation rate of Melipona subnitida is due to the location of the harvesting area in the immediate proximity of man-made colony boxes as well as the availability of larval food (pollen) and material (oil) for sealing the colony entrance from the plant. Siqueira et al. (2007), analyzing several stingless bee species nests, found their entrances to be mainly composed of plant resins and animal feces. The presence of resins in Mouriri species and the exploitation of the glands of these species by Melipona bees have previously been observed (Buchmann and Buchmann 1981). The present work shows evidence that $M$. subnitida utilizes $M$. guianensis floral oil. The sealing of the entrance at night and reopening in the morning occurred in a pattern similar to that seen in other Meliponinae such as Tetragonisca angustula Latreille (Cortopassi-Laurino and Nogueira-Neto 2003).

Although Meliponinae are specialized in harvesting floral resins for building the wall of their nests (Agostini $e t$ al. 2014), their harvesting of floral oils from Mouriri flowers has already been reported (Buchmann and Buchmann 1981; Renner 1984). Trigona pallens Fabricius were observed on the elaiophores of Mouriri myrtilloides subsp. parvifolia (Benth.) Morley in Panamá (Buchmann and Buchmann 1981). The behavior of scraping the floral connective glands to harvest the oil that would probably be mixed with pollen has been observed in Trigona williana Friese, Melipona fulva Lepeletier and M. marginata Lepeletier, whereas nine species (six Euglossa and three Xylocopa) only harvested pollen (Renner 1984). Most likely, the oil harvesting makes it easy for the pollen grains to adhere to the smooth ventral surface of these bees and increases the amount of rewards to be carried (Rêgo and Albuquerque 1989).

The flowers of M. guianensis produce an odor that is strongly emitted during the night. Thus, the bees capacity to detect smells may have an important role in searching for flowers at twilight conditions (Knoll and Santos 2012). Most likely, bees use these floral scents to help them with the location of pollen sources, an important factor for foraging bees in low-light conditions (Dobson and Bergström 2000; Wcislo et al. 2004).

The flowers of M. guianensis secrete an aromatic oil used by the visiting bees. However, the oil from Mouriri could not be viewed as a floral reward because its ecological functions 
for the bees exploiting it remain not fully defined; so far as we know, it only serves to facilitate the adherence of pollen grains to the thorax of the Epicharis and Trigona bees (Buchmann and Buchmann 1981; Steiner 1985; Agostini et al. 2014). Although no floral oil harvesting-specialized bee species, such as Centridini, Tapinotaspidini and Tetrapediini, were found visiting $M$. guianensis flowers, evidence of the exploitation and use of the oil from Mouriri flowers by their visiting bees (Trigona sp., M. amoena and M. subnitida) was observed; thus, this oil appears important to them.

Visiting bees, apart from Augochloropsis sp. and Trigona sp., were considered potential pollinators of M. guianensis, considering their harvesting behaviors and body sizes. While they vibrate, bees hold themselves to a group of stamens, bending their entire bodies over it, shortening the distance to the stigma and transferring pollen grains.

\section{CONCLUSIONS}

From our results, we conclude that $M$. guianensis is an important source of resources for the pollinating bees that collect pollen via the specific vibration mechanism known as buzz pollination. Additionally, evidence for the use of oil by M. subnitida characterizes Mouriri as important species for these bees in the study area. Additionally, this plant species, despite being associated with the daytime visits of bees, attracts and is pollinated by crepuscular bees, presenting a case of a crepuscular pollination system. Thus, we suggest that both daytime and nighttime visitors can act in a complementary manner in the pollination process. However, further studies are needed to confirm this hypothesis. Finally, the data of the present study will serve to strengthen knowledge about Mouriri as well as about the mechanisms related to plant interaction and crepuscular bees.

\section{ACKNOWLEDGMENTS}

We thank Mr. Emídio Santos Aguiar and Mrs. Irene Aguiar Santos for allowing us to use the sampling area and for their support and friendship throughout all the steps of this work. We are grateful to Drs. Gabriel A. R. Melo and Leandro M. Santos (UFPR) for their help in identifying the species, to Jorge M. Antunes for his help in drafting the English version of the original manuscript and Gracy Chrisley A. Carvalho for the pictures of the figure 5. Thanks are also offered to the Instituto Chico Mendes de Conservação da Biodiversidade - ICMBio)/ Sistema de Autorização e Informação em Biodiversidade SISBIO, Protocol number 47580-1), to the Research and Scientific Development Foundation of Maranhăo - FAPEMA (Grant number 1018/13, PROBATION 466/13 and POSGRAD 03431/13) for their financial support, and to the High Level Personnel Improvement Coordination - CAPES for a scholarship grant.

\section{REFERENCES}

Agostini, K.; Lopes, A.V.; Machado, I.C. 2014. Recursos florais. In: Rech, A.R.; Agostini, K.; Oliveira, P.E.; Machado, I.C. Biologia da Polinização. Rio de Janeiro, Projeto cultural, p. 129-150.

Aguilar-Rodriguez, P.A.; Kromer, T.; Garcia-Franco, J.G.; MacSwiney, M.C. 2015. From dusk till dawn: nocturnal and diurnal pollination in the epiphyte Tillandsia heterophylla (Bromeliaceae). Plant Biology, 18:37-45.

Bencke, C.S.C.; Morellato, L.P. C. 2002. Comparação de dois métodos de avaliação da fenologia de plantas, sua interpretação e representação. Revista Brasileira de Botânica, 25: 269-275.

Brasil. Instituto Brasileiro do Meio Ambiente e Recursos Naturais Renováveis - IBAMA, Ministério do Meio Ambiente. 2002. Plano de Manejo: Parque Nacional dos Lençóis Maranhenses. Brasília, 499p.

Brito,V.; Telles, F.; Lunau, K. 2014. Ecologia cognitiva da polinização. In: Rech, A.R.; Agostini, K.; Oliveira, P.E.; Machado, I.C. Biologia da Polinização. Rio de Janeiro, Projeto cultural, p. 418-438.

Buchmann, S.L; Buchmann, M.D. 1981. Anthecology of Mouriri myrtilloides (Melastomataceae: Memecyleae), an oil flower in Panama. Biotropica, 13: 7-24.

Buchmann, S.L. 1983. Buzz pollination. In: Jones, C.E.; Little, R.J. (Ed.). Handbook of Experimental Pollination Biology. Van Nostrand Reinhold, New York, p. 73-113.

Cortopassi-Laurino, M.; Nogueira-Neto, P. 2003. Notas sobre a bionomia de Tetragonisca weyrauchi schwarz, 1943 (Apidae, Meliponini). Acta Amazonica, 33:643-650.

Cruden, R.W. 2000. Pollen grains: Why so many? Plant Systematics and Evolution, 222:143-165.

De Luca, P.A.; Vallejo-Marín, M. 2013. What's the "buzz" about? The ecology and evolutionary significance of buzzpollination. Current Opinion in Plant Biology, 16: 429-435.

Dobson, H.E.M.; Bergsrtöm, G. 2000. The ecology and evolution of pollen odors. Plant Systematics and Evolution, 222:63-87.

Erdtman, G. 1960. The Acetolysis Method. A Revised Description. Svensk Botanisk Tidskrift, 54: 561-564.

Fournier, L.A. 1974. Un método cuantitativo para la medición de características fenológicas en árboles. Turrialba, 24: 422-423.

Franco, E.L.; Gimenes, M. 2011. Pollination of Cambessedesia wurdackii in Brazilian campo rupestre vegetation, with special reference to crepuscular bees. Journal of Insect Science, 2: 1-13.

Freitas, L.; Vizentin-Bugoni, J.; Wolowski, M.; Souza, J.M.T. de Varassin, I.G. 2014. Interaçôes planta-polinizador e a estruturaçâo das comunidades. In: Rech, A.R.; Agostini, K.; Oliveira, P.E.; Machado, I.C. Biologia da Polinização. Rio de Janeiro, Projeto cultural, p. 373-397.

Junker, R.R.; Blüthgen, N. 2010. Floral scents repel facultative flower visitors, but attract obligate ones. Annals of Botany, 105:777-782.

Knoll. F.R.N.; Santos, L.M. 2012. Orchid bee baits attracting bees of the genus Megalopta (Hymenoptera, Halictidae) in Bauru region, São Paulo, Brazil: abundance, seasonality, and the importance 
of odors for dim-light bees. Revista Brasileira de Entomologia, 56: $481-488$.

Locatelli, E.; Machado, I. C. 2004. Fenologia das espécies arbóreas de uma Mata Serrana (Brejo de Altitude) em Pernambuco, Nordeste do Brasil. In: Porto, K. C.; Cabral, J.J.; Tabarelli, M. (Org.). Brejos de altitude: história natural, ecologia e conservação. MMA/PROBIO, Brasília, p. 255-276.

Lunau, K.; Papiorek S.; Eltz, T.; Sazima, M. 2011. Avoidance of achromatic colours by bees provides a private niche for hummingbirds. Journal of Experimental Biology, 214:16071612.

Martins, A.C. 2013. Historical approaches in the study of plantpollinator interactions. Oecologia Australis, 17: 39-52.

Newstrom, L.E.; Frankie, G.W.; Baker, H.G. 1994. A new classification for plant phenology based on flowering patterns in lowland tropical rain forest trees at La Selva, Costa Rica. Biotropica, 26:141-159.

Odum, E.P. 1971. Fundamentos da ecologia. Fundação Calouste Gulbenkian, 3a edição, Lisboa, 595p.

Oliveira-Rebouças, P.; Gimenes, M. 2004. Abelhas (Apoidea) Visitantes de Flores de Comolia ovalifolia DC Triana (Melastomataceae) em uma Área de Restinga na Bahia. Neotropical Entomology, 33:315-320.

Oliveira, F.S. 2010. Biologia reprodutiva e sistema de polinizaçâo de "criuli" Mouriri acutiflora Naudin (Melastomataceae). Dissertação de Mestrado, Universidade Federal do Maranhão, São Luis, Maranhão, Brasil, 42p.

Rêgo. M.M.C.; Albuquerque, P.M.C. 1989. Comportamento das abelhas visitantes de murici, Byrsonima crassifolia, (L.) Kunth, Malpighiaceae. Boletim do Museu Paraense Emilio Goeldi, 5:179-193.

Renner, S.S. 1984. Phaenologie, Bluetenbiologie, und Rekombinationsystemes einiger zentralamogonisher Melastomataceen. Tese de doutorado, Universidade de Hamburg.

Siqueira, E.L.; Martinez, R.B.; Nogueira-Ferreira, F.H. 2007. Ninhos de abelhas sem ferrão (Hymenoptera, Meliponina) em uma região de Araguari-MG. Bioscience Journal, 23: 38-44.
Smith, A.R.; Quintero, I.J.L.; Patino, J.E.M.; Roubik, D.W.; Wcislo, W.T. 2012. Pollen use by Megalopta sweat bees in relation to reward availability in a tropical forest. Ecological Entomology, 37: 309-317.

Steiner, K.E. 1985. The role of nectar and oil in the pollination of Drymonia serrulata (Gesneriaceae) by Epicharis-bees (Anthophoridae) in Panama. Biotropica, 17:217-229.

Thompson, J.N. 1989. Concepts of coevolution. Trends in Ecology and Evolution, 4: 179-183.

Warrant, E.J, Kelber A, Wallén R, Wcislo W.T. 2006. Ocellar optics in diurnal and nocturnal bees and wasps. Arthropod Structure and Development, 35: 293-305.

Westerkamp, C. 1997. Flowers and bees are competitors - not partners: towards a new understanding of complexity in specialized bee flowers. Acta Horticulturae, 437:71-74.

Wcislo, W.T.; Arneson, L.; Roesch, K.; Gonzalez, V.H.; Smith, A.; Fernandez, H. 2004. The evolution of nocturnal behaviour in sweat bees, Megalopta genalis and M. ecuadoria (Hymenoptera: Halictidae): an escape from competitors and enemies? Biological Journal of the Linnean Society, 83: 377-387.

Wcislo, W.T.; Tierney, S.M. 2009. Behavioural environments and niche construction: the evolution of dim-light foraging in bees. Biological Reviews of the Cambridge Philosophical Society, 84: 19-37.

Vallejo-Marin, M.; Manson, J.S.; Thomson, J.D.; Barrett, S.C.H. 2009 Division of labour within flowers: heteranthery, a floral strategy to reconcile contrasting pollen fates. Journal of Evolutionary Biology, 22:828-839.

Viana, B.F.; Kleinert, A.M.P.; Silva, F. 2002. Ecologia de Xylocopa (Neoxylocopa) cearensis (Hymenoptera, Anthophoridae) nas dunas litorâneas de Abaeté, Salvador, Bahia. Iheringia, 92:47-57.

Vogel, S. 1974. Olblumen und olsammelnde Bienen. Akad. Wissenschaften u. Literature Mainz. Wiesbaden: Franz Steiner, $547 \mathrm{p}$.

Recebido 27/10/2015

Aceito em 18/03/2016 
